\title{
TRANSITION IN AFGHANISTAN
}

\section{LOOKING BEYOND 2014}

November 21, 2011

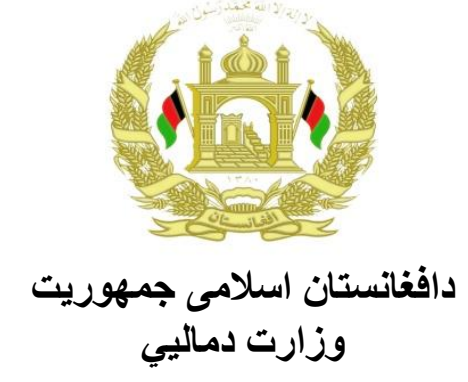

Islamic Republic of Afghanistan

Ministry of Finance 


\section{$2 \quad$ Context of transition}

$>$ Full responsibility for security is to be handed over and most international troops are to be withdrawn by the end of 2014-as understood at the 2010 Kabul and Lisbon conferences

$>$ Experience suggests that withdrawals of international troops reduce civilian aid, with implications for economic growth, fiscal sustainability, and service delivery

$>$ Potential financing gaps in the budget could threaten security and recent development progress, creating a sense of urgency for both the Government and the donor community 


\section{$3 \quad$ This presentation}

Lays out the size and delivery mechanism for aid

> Discusses implications for government finances and service delivery

> Traces the impact of the possible decline in aid on economic growth

> Shares lessons from international experience

$>$ Suggests a way forward. 
Aid in Afghanistan: Size and delivery mechanism 


\section{Afghanistan: One of the world's largest recipients of aid}

$>$ Aid in 2010-11 was about $\$ 15.7$ billion - about the size of nominal GDP

$>$ Only a few other countries receive similar levels of aid (such as Liberia, West Bank and Gaza)

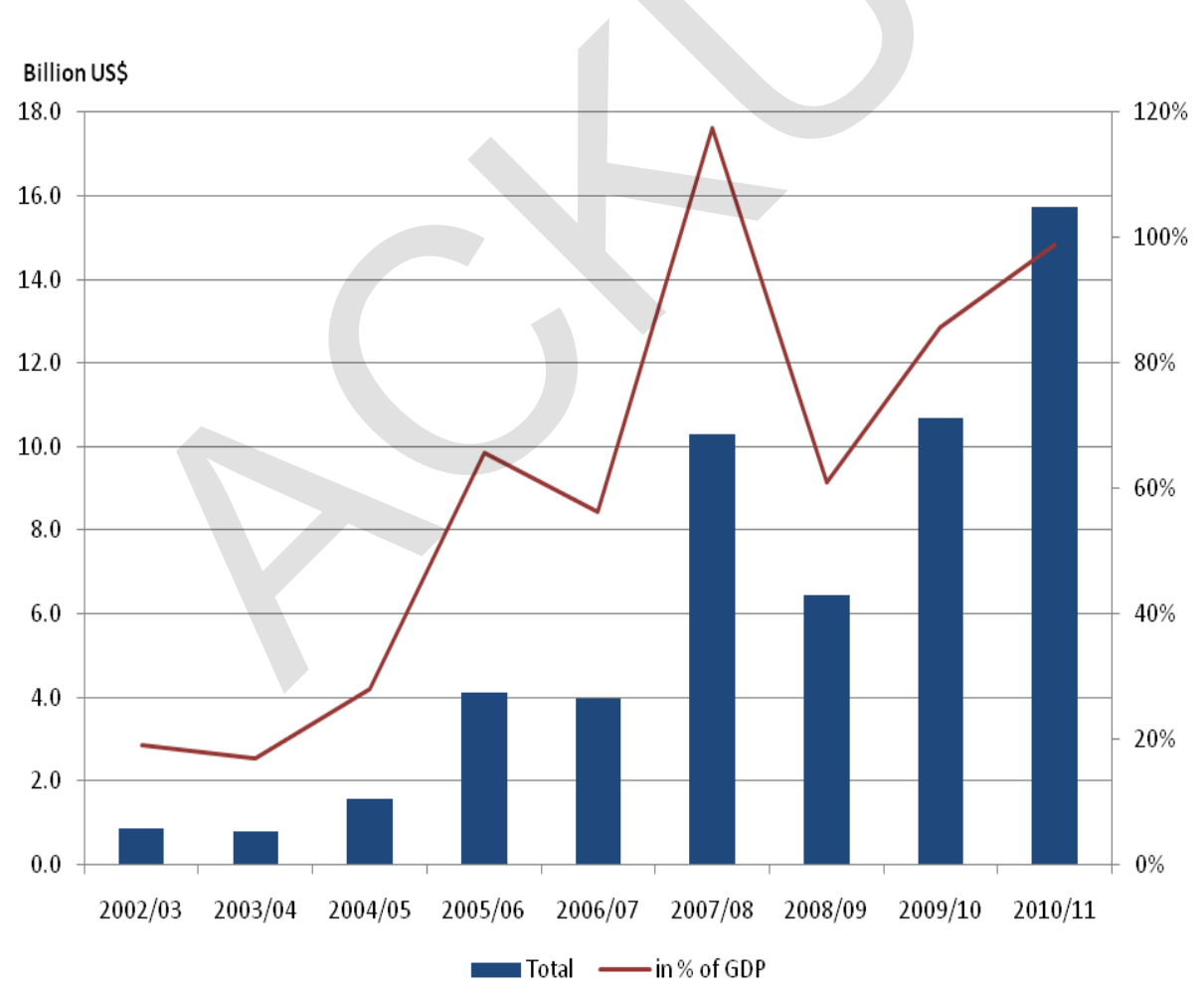

Note: Aid estimates reflect actual disbursements and donor surveys, cross-tabulated with several reporting sources (SIGAR audits, US treasury contracting reports, and the like). 


\section{Aid is delivered in different ways}

> In 2010/11, total public spending, including the "core budget" and "external budget," was \$17.1 billion

> Of this total spending, $\$ 15.7$ billion was financed by aid, $\$ 1.9$ billion of it "on budget"

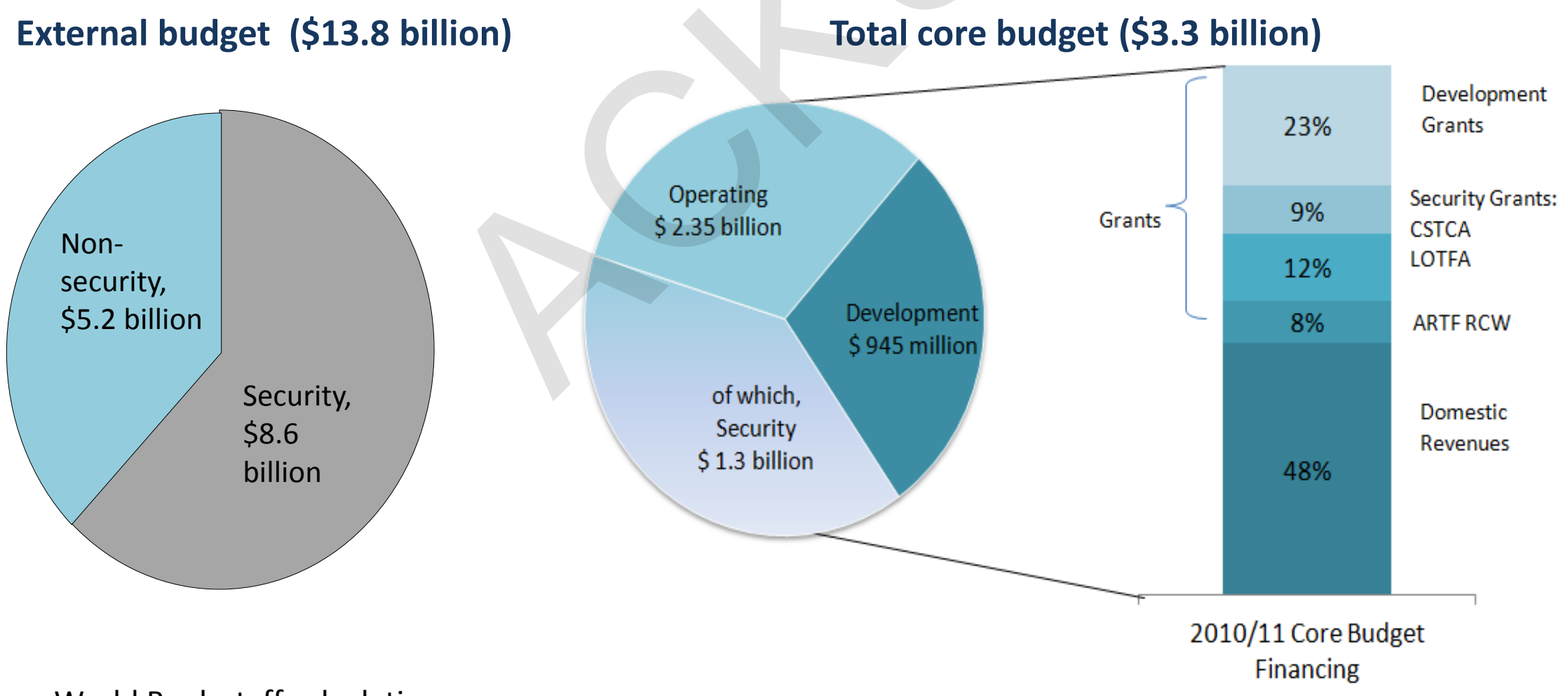

Source: World Bank staff calculations. 


\section{Not all money "for" Afghanistan is spent "in" Afghanistan}

> For example, cumulative US spending for the Afghanistan mission is estimated to be as high as $\$ 444$ billion ( $\$ 118.6$ billion in FY2011 alone)

$>$ But most of that spending does not reach Afghanistan because it primarily funds salaries of international soldiers, purchases of military hardware, and the like

> And not even all aid spent "in" Afghanistan feeds into the domestic economy, as it goes out in imports of goods and services, expatriated profits, and remittances

Local content of aid in Afghanistan (\%)

\begin{tabular}{|l|c|c|}
\hline & On budget & External budget \\
\hline Security-related aid & $90-95$ & $10-15$ \\
\hline Civilian aid & $<70$ & $20-25$ \\
\hline
\end{tabular}

Source: World Bank staff estimates. 


\section{Domestic revenues are projected to increase, but operating spending is likely to grow faster}

- Domestic revenues are projected to increase from $10 \%$ of GDP to $17.5 \%$ by $2021 / 22$, driven largely by the planned value added tax and mining revenues

But over the same period, operating spending on

Security: Wage bill to increase from $7 \%$ of GDP to $10 \%$ to reach 352,000 troops and Operations \& Maintenance (O\&M) from 1\% to $10.5 \%$ of GDP ( $\$ 3.5$ billion annually in 2011 prices) by $2014 / 15$

Non-security: Civil service wage bill will increase from $5 \%$ of GDP to $9 \%$, and O\&M spending required to sustain donor capital investments from $1 \%$ to $4 \%$ by $2014 / 15$ ( $\$ 1.3$ billion in 2011 prices)

Combined, these operating expenditures will be almost twice the size of domestic revenues by $2021 / 22$
Total budget expenditure and revenues

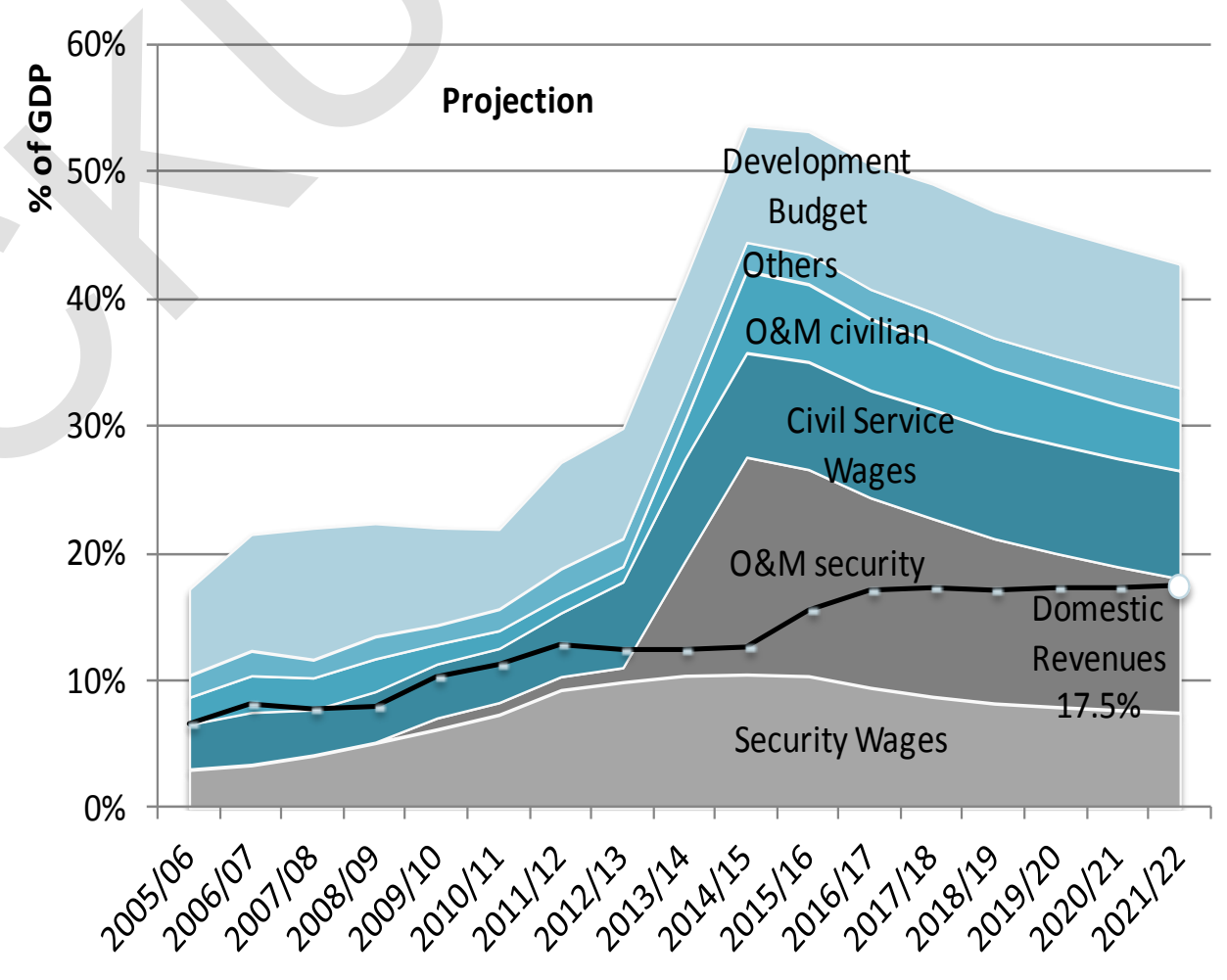

Source: World Bank staff calculations. 


\section{Projected financing gap-around 25\% of GDP in 2021/22}

The composition of projected expenditures:

> Additional security spending (O\&M plus wages) is $14.5 \%$ of GDP, with the current Afghan contribution at $3 \%$ of GDP

$>$ Non-security (operating) spending is $15.5 \%$ of GDP

$>$ Development spending is $10 \%$ of GDP (assuming a 10\% annual improvement in budget execution)

Total projected expenditures ( $43 \%$ of GDP) less projected domestic revenues $(17.5 \%$ of GDP) leaves a projected financing gap of around $25 \%$ of GDP ( $\$ 7.2$ billion in 2011 prices)

Note: This is a snapshot of projected expenditures in 2021/2022; changes over time are in the previous slide.
Fiscal 2021/22 projections (\% of GDP)

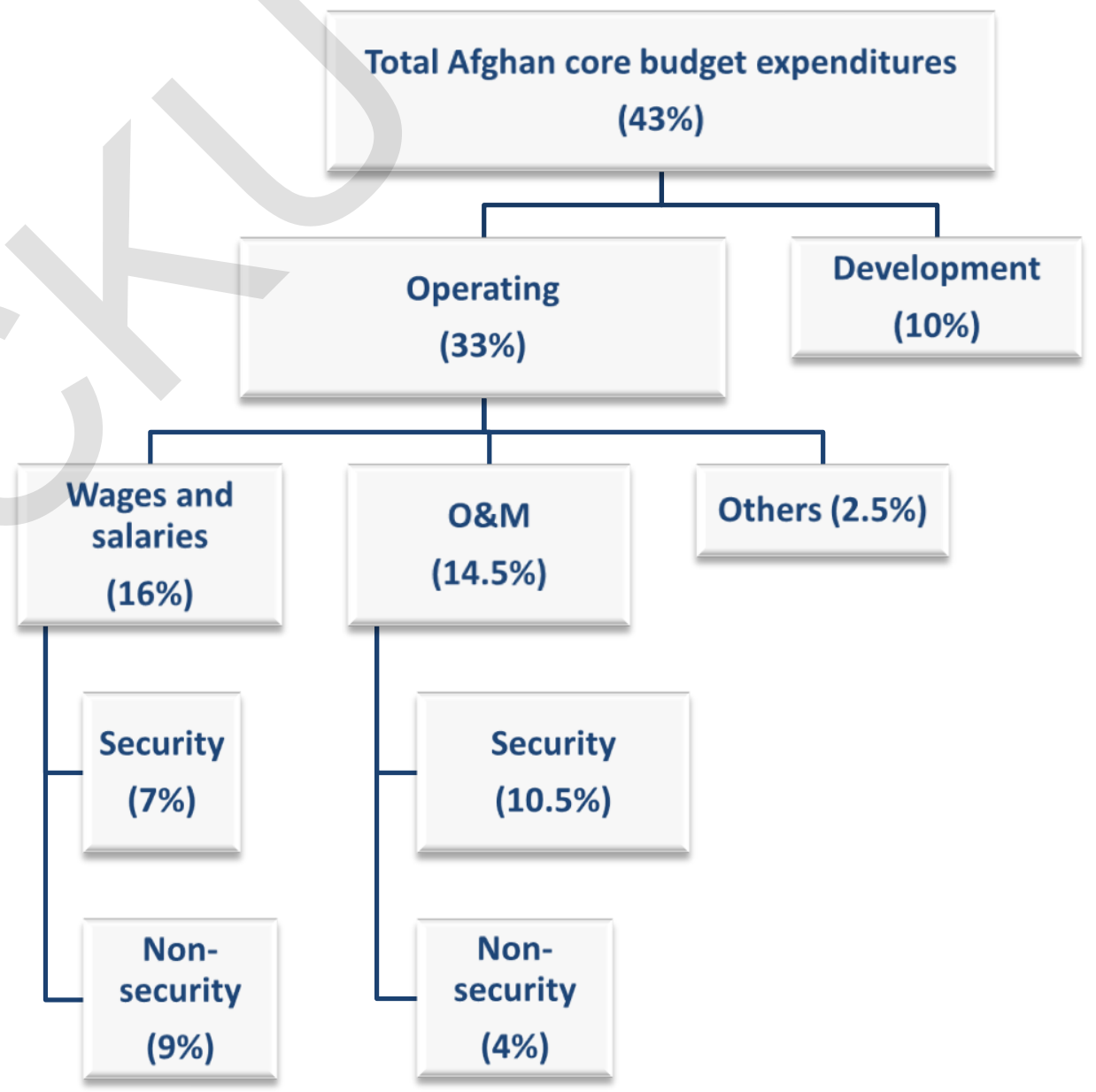




\section{Managing the financing gap in $2021 / 22$}

\section{5\% of GDP (\$7.2 billion in 2011 prices)} would bridge the gap in 2021/22

While aid could finance any combination of these expenditures, a reasonable option to fill the gap could be:

$>$ The Afghan budget funds civilian O\&M ( $\$ 1.3$ billion) and a contribution to the security wage bill at 2010 level

$>$ Donors absorb the additional increasing security expenditures (that is, security wages plus security O\&M)

$>$ Donors increase on-budget contributions by around $11 \%$ in development budget grants
Financing gap with and without security

(\% of GDP, excluding grants)

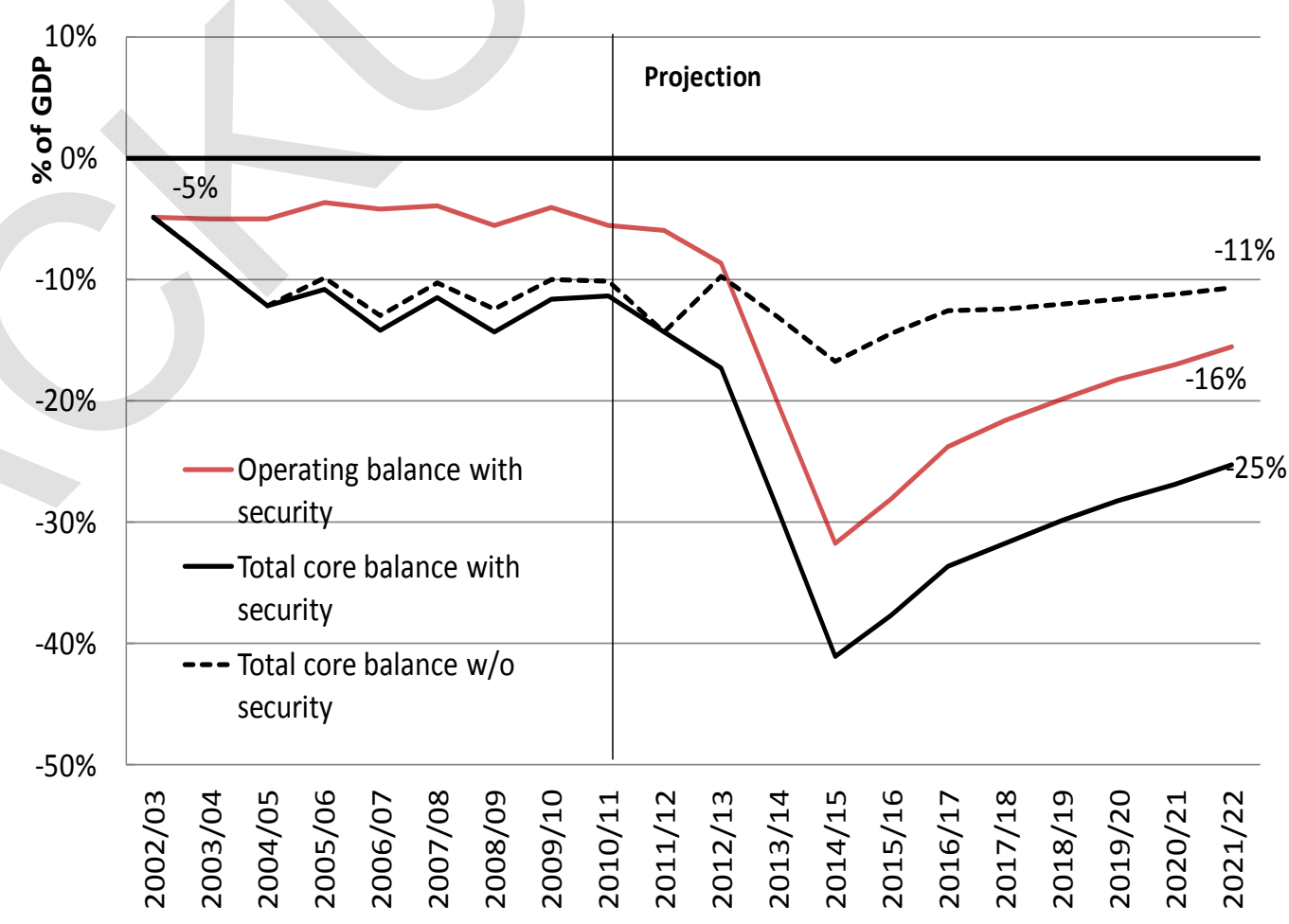




\section{Financing gap of this size cannot be sustained}

The financing gap requires either filling with international assistance or making dramatic expenditure cuts:

Reducing security spending will mean:

$>$ Smaller ANSF and ANP and/or underfunding of security O\&M

$>$ Fewer operations and poor security infrastructure

$>$ Deteriorating security could threaten private sector development and mining investment and reduce revenue from mining

Or

Financing security from domestic resources will crowd out:

$>$ Funding for development projects, undermining service delivery

$>$ Civilian O\&M spending - leading to a deterioration of donor built assets

$>$ Spending on civil service reform-undermining government capacity and quality in service delivery 


\section{Boosting absorptive capacity}

$>$ Development budget execution increased in absolute terms, but flattened out at below \$1 billion over last four years, largely due to capacity constraints, unrealistic budget formulation, and donor earmarking and funding delays

While the execution of the operational budget has been historically high, Afghanistan does not have capacity to handle large O\&M expenditures (O\&M only accounts for roughly $\$ 335$ million, or $10 \%$ of total core expenditure), which are expected to increase to $\$ 4.8$ billion by $2015 / 16$

There are problems with efficiently allocating funds from the center to provinces/districts and considerable weaknesses in government capacity at sub-national levels.

Investing in government capacity in budget Total core development budget execution

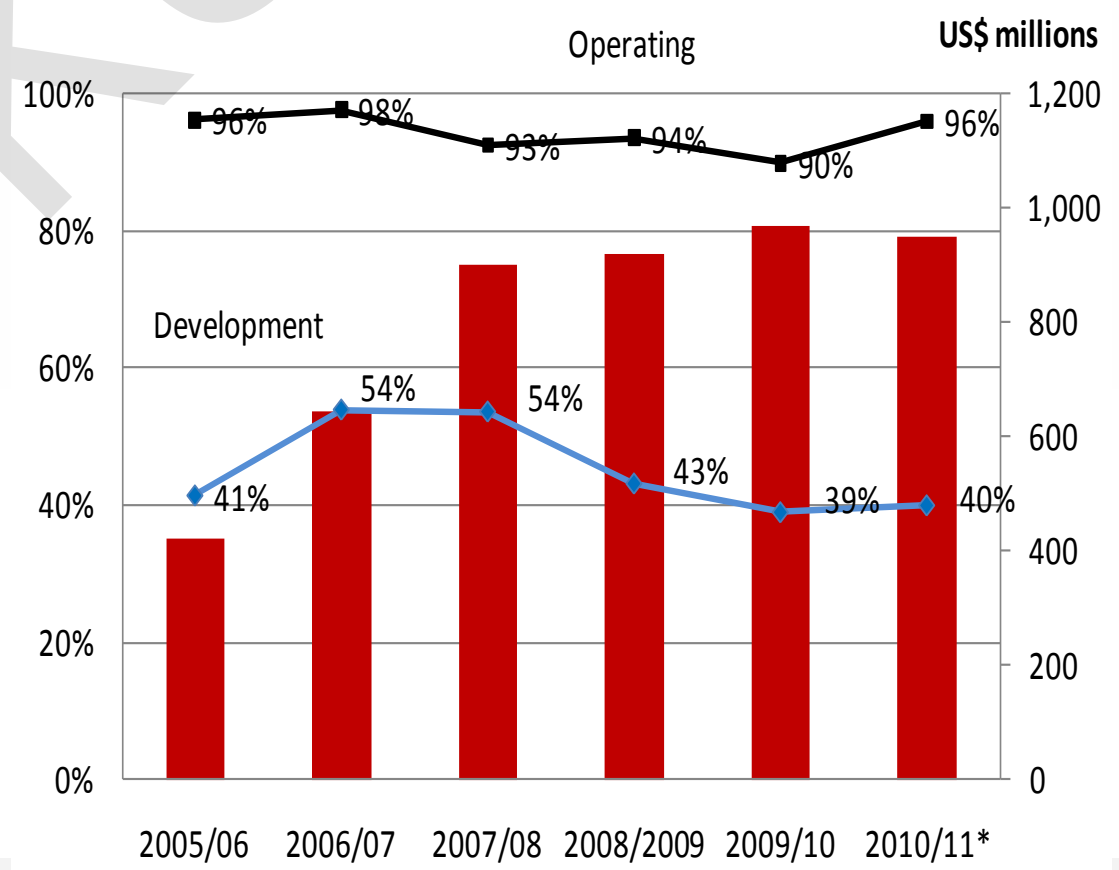
management therefore remains an important priority 


\section{Building capacity to increase budget execution and deliver services}

$>$ To maintain and increase on-budget spending and service delivery, urgent action is needed to build the core capacity of line ministries, and ensure that skilled staff can be recruited and retained by government in the medium term

- While large amounts have been spent on capacity building, it has created a fragmented "second civil service" of an estimated 7,000 skilled Afghan consultants managing projects, without building sufficient government capacity.

$>$ In nine ministries, externally funded staff (EFS) make up only $5 \%$ of positions but $40 \%$ of payroll costs. Reductions in EFS positions in transition would compromise service delivery as the burdens on government increase

$>$ Donors should support efforts to reduce inflated salary scales and build government capacity in a strategic and targeted manner by transferring capacity from the second civil service to the core civil service. This would be more cost-effective and provide greater stability 


\section{Delivery of basic services is at risk}

> Services are threatened by reductions in project-based donor funding and/or by continued underfunding of O\&M.

$>$ Risks vary between sectors:

$>$ Transport and health are highly vulnerable due to high reliance on donorfunding and low O\&M spending

- Electricity is less vulnerable, due to potential recovery of costs through user fees

$>$ Although less reliant on donors, O\&M in education is underfunded.

\begin{tabular}{|c|c|c|c|c|c|}
\hline & Education & Health & Rural & Transport & Power \\
\hline $\begin{array}{l}\text { Donor contributions to } \\
2011 / 12 \text { dev't budget } \\
\text { (\% of core budget) }\end{array}$ & $\begin{array}{l}\$ 163 m \\
(23 \%)\end{array}$ & $\begin{array}{c}\$ 124 m \\
(62 \%)\end{array}$ & $\begin{array}{c}\$ 358 m \\
(83 \%)\end{array}$ & $\begin{array}{c}\$ 253 m \\
(73 \%)\end{array}$ & $\begin{array}{l}\$ 89 m \\
(50 \%)\end{array}$ \\
\hline $\begin{array}{c}\text { Estimated O\&M } \\
\text { requirements in 2014 } \\
\text { (shortfall }[2011 / 12] \text { ) }\end{array}$ & $\begin{array}{c}\$ 235 m \\
(-\$ 205 m)\end{array}$ & $\begin{array}{c}\$ 77 m \\
(-\$ 67 m)\end{array}$ & $\begin{array}{c}\$ 11 m \\
(-\$ 3 m)\end{array}$ & $\begin{array}{c}\$ 394 m \\
(-\$ 317 m)\end{array}$ & $\begin{array}{c}\$ \mathbf{2 9 7 m} \\
(-\$ 258 \mathrm{~m})\end{array}$ \\
\hline
\end{tabular}

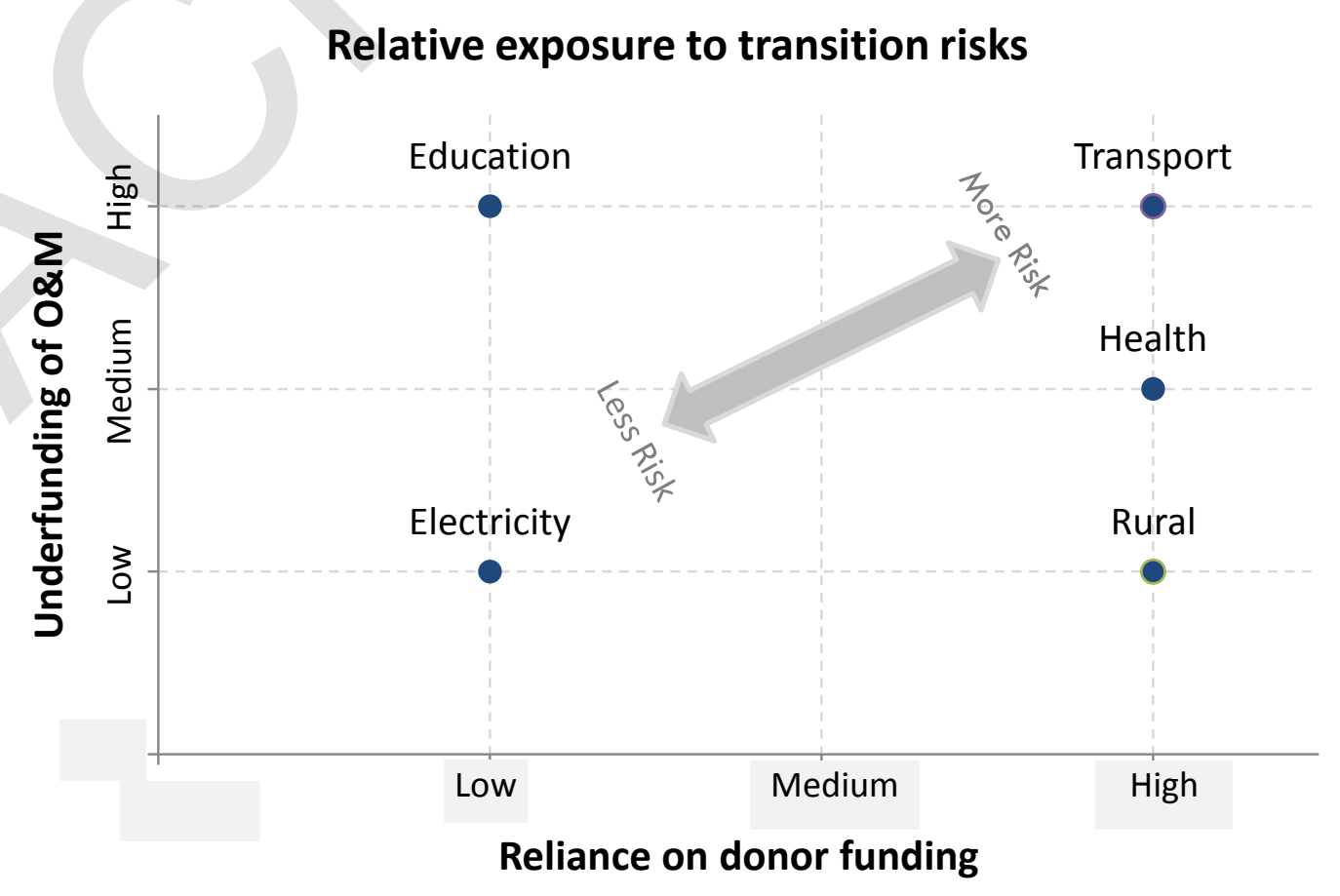




\section{As aid declines, Afghanistan will face an increasingly hard budget constraint over the coming years, so...}

> Tough expenditure choices need to be made (both by the Government and donors):

$>$ Choosing investment projects that are growth-enhancing and affordable and that can be operated and maintained

> Prioritizing O\&M spending, which will require inter- and intra-sectoral trade-offs

$>$ Maintaining social spending and delivering basic services (education, health, rural livelihoods)

> Revenue collection needs to improve to reach planned targets. To minimize leakage:

$>$ Forcefully implement customs reforms

> Enhance capacity in tax administration to implement the value-added tax

$>$ Establish robust accountability mechanisms for managing mineral revenues

> Government capacity to implement on-budget financing needs to improve. 
17 Aid and economic growth 


\section{The state of development: Some indicators}

$>$ Afghanistan remains one of the least developed countries

> A nation of 30.6 million people with a per capita GDP of \$528 in 2010/11, among the poorest 10 countries

$>$ In $2008,36 \%$ of the population lived below the poverty line; more than half of the population is considered vulnerable

$>$ Infant mortality (134 per 1,000 live births) is highest in the world

$>$ Life expectancy is 48.1 years

> $75 \%$ of the population is illiterate

$>$ With population growth at $\mathbf{2 . 8 \%}$, Afghanistan needs strong economic growth to reduce poverty and improve development outcomes

A growth rate of $6 \%$ a year would be required to double Afghanistan's per capita GDP in about 22 years (in about a generation) 


\section{Economic growth in recent years}

> Average GDP growth over FY 2003/04-10/11 was 9.1\% (8.4\% without "outlier" years)

$>$ Private investment (8.5\% of GDP) and exports (2.5\% of GDP) have been low; GDP growth has been mainly driven by consumption

> Mining is expected to be a major contributor to growth

$>$ Severe constraints to future growth: conflict, landlocked, and narrow economic base

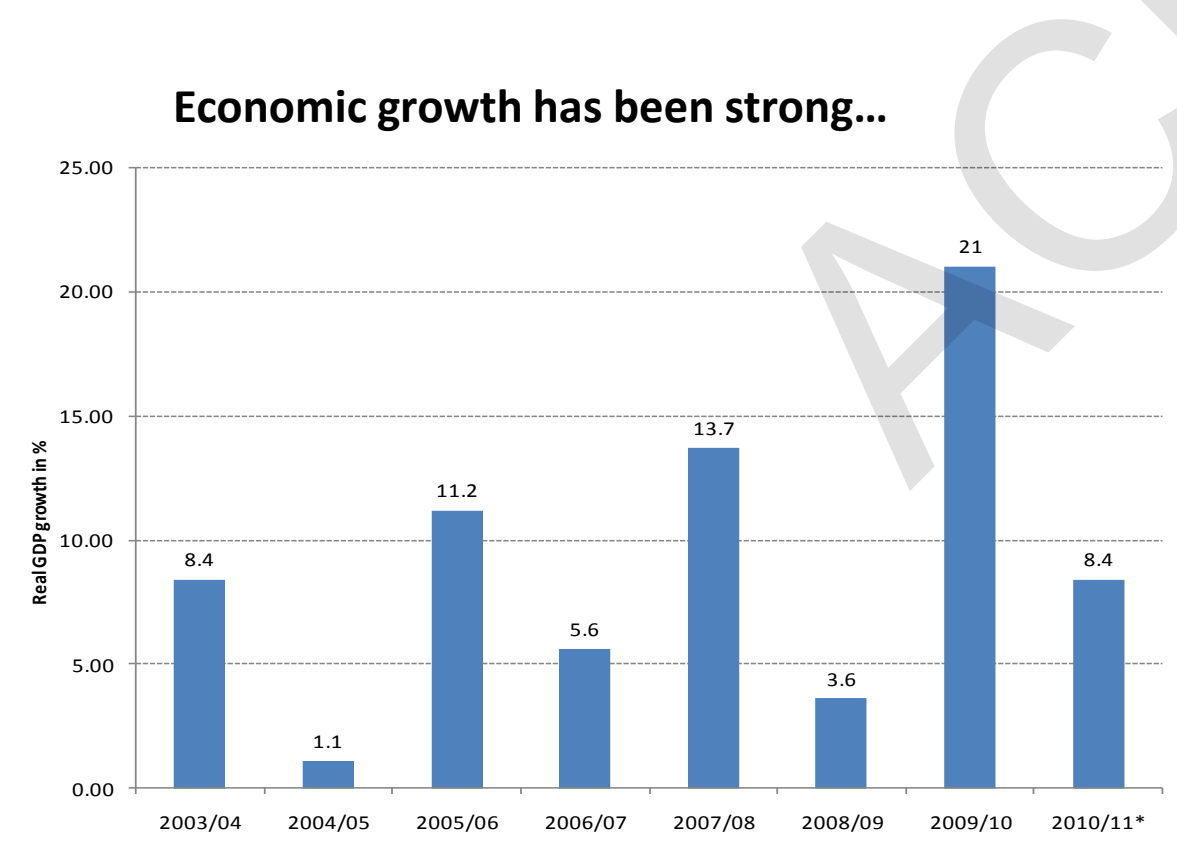

....and sensitive to changes in agricultural production

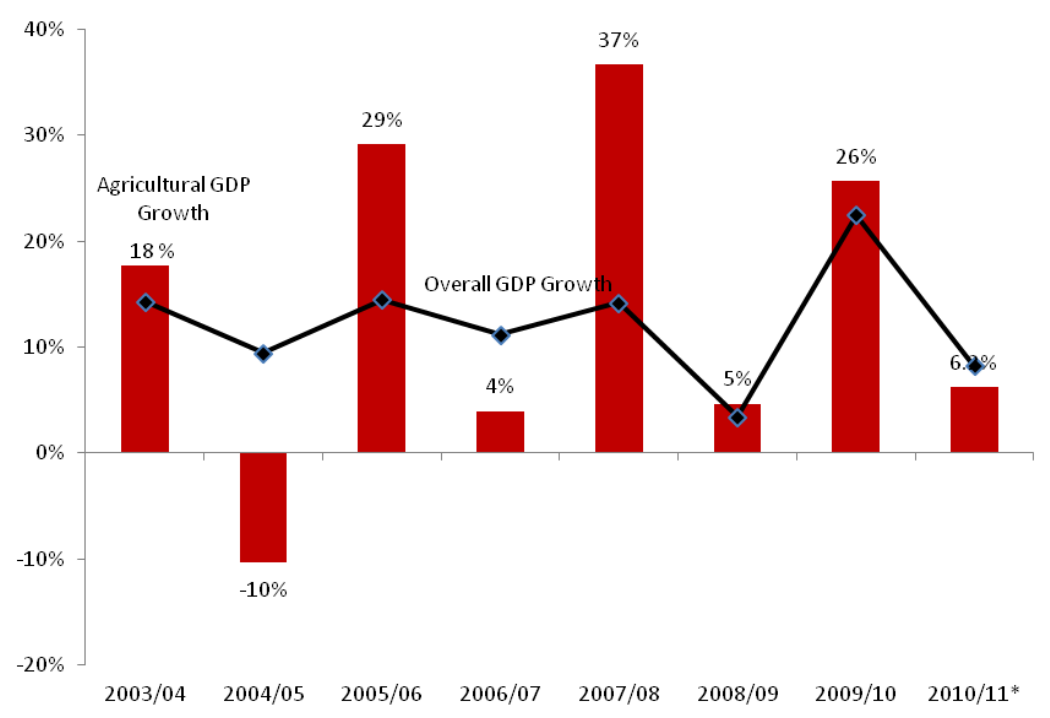




\section{Security is critical for economic growth}

The economic outlook is very sensitive to drought, security, changes in fuel and food prices and governance

$>$ In the more favorable scenarios (BASE and AGRIC-), the economy is projected to grow between $4.5 \%$ and $6.2 \%$ annually between 2011 and 2018 and converge to around 3-4\%further improvements in investment climate and infrastructure (starting now) could lead to even higher growth (MIN+).

$>$ Any serious deterioration in security or governance (Gov-) could lead to negative growth

\section{Main assumptions}

BASE: Gradual decline in aid (10\% of GDP by 2025); improving investment climate; opium economy assumed to remain constant (no growth); slower/negative growth in construction, transportation, and retail

AGRIC- : Historical growth rates for agriculture $-4 \%$ a year on average

Gov-: Rapid decline in aid, no mining, zero productivity growth, and strong depreciation of capital

Min+: BASE plus 11 additional mines, all developed over simplified timeframe

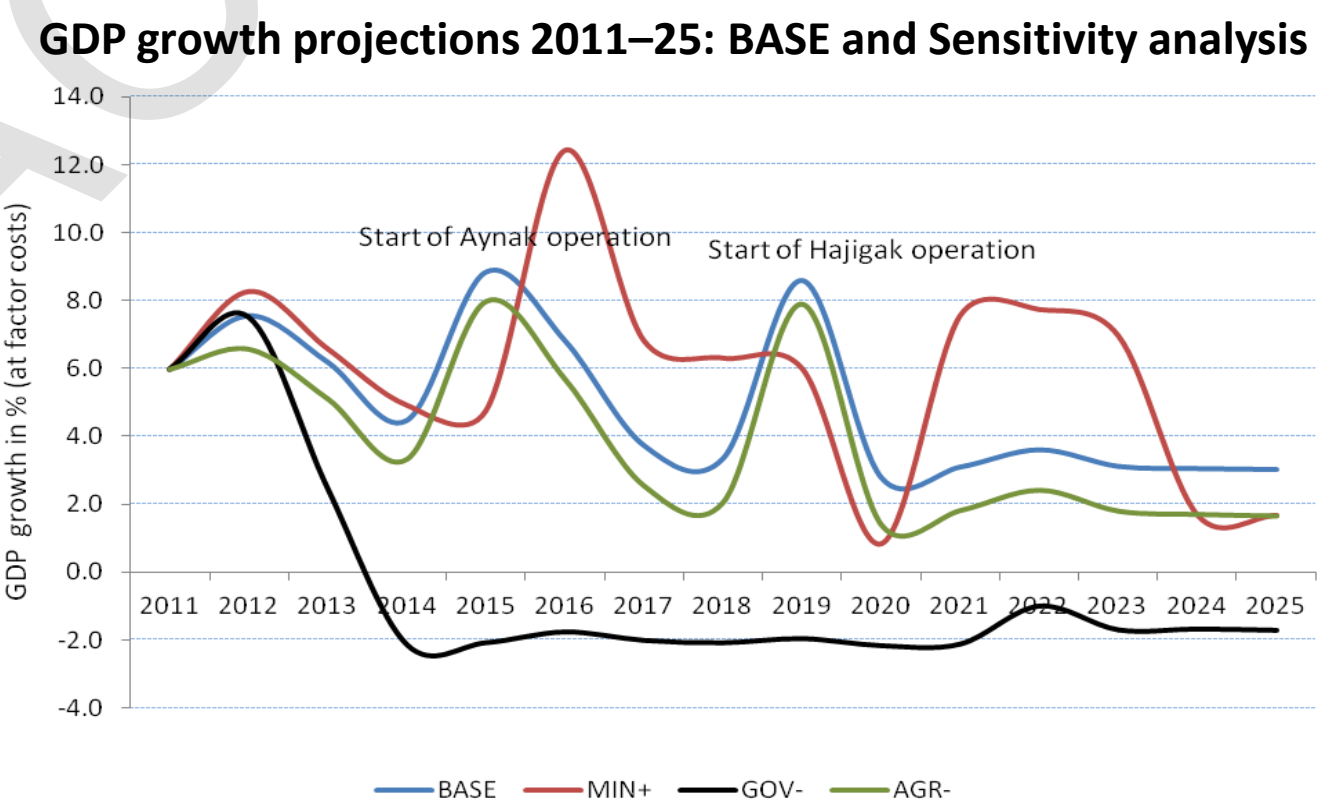




\section{How does the scale-down of aid affect growth?}

\section{Main assumptions}

BASE: Gradual decline in aid (10\% of GDP by 2025); improving investment climate

AID-: Like BASE, but rapid decline in aid (reaching $10 \%$ of GDP in 2018)

AIDALLOC: Like BASE, but $50 \%$ of aid on budget with full execution

GDP growth projections 2011-25: Aid scenarios

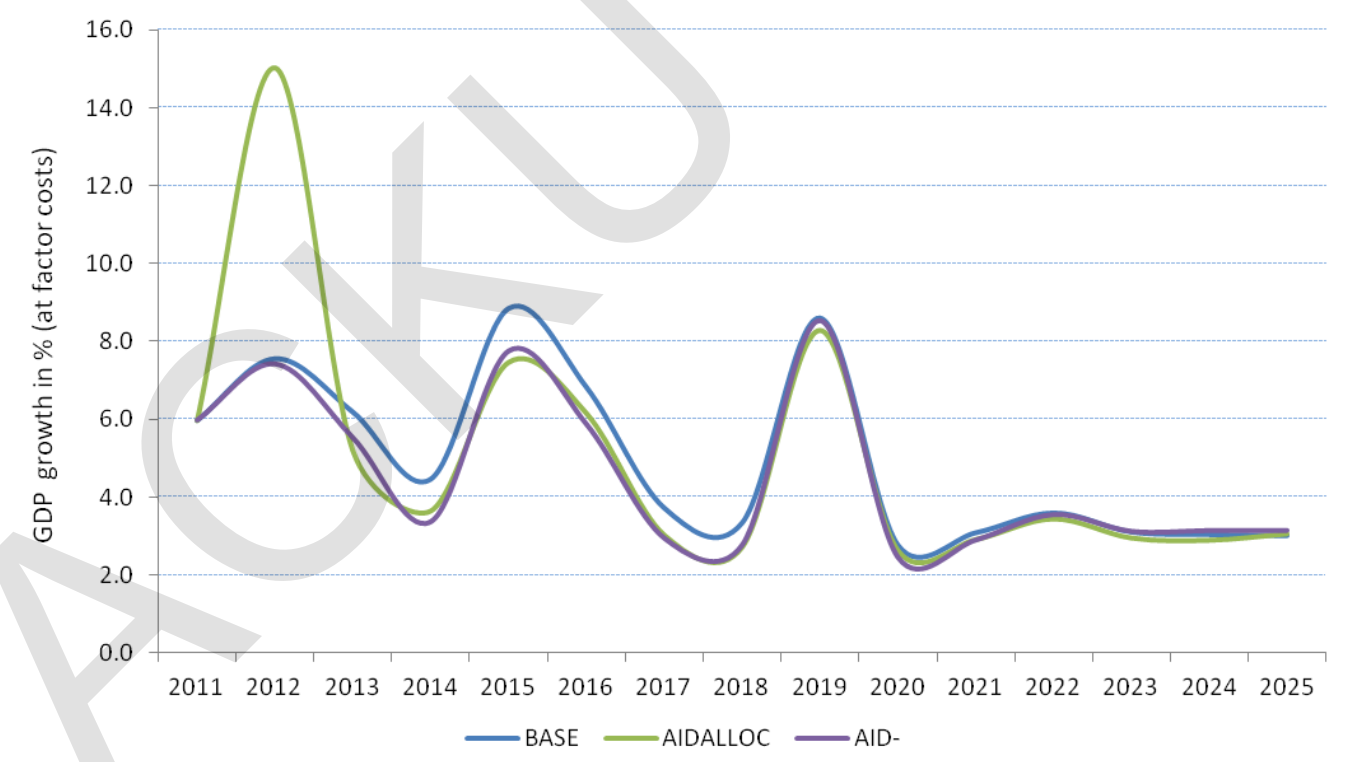

> A rapid decline of aid would reduce growth to 5.5\% until 2018 and around $3 \%$ in the long term due to less consumption and investment. This is roughly 1 percentage point on average than the BASE scenario, or roughly $50 \%$ less than current growth.

$>$ Putting more aid on budget (the AIDALLOC scenario) increases the local content of aid and can mitigate some of the negative impact during the early years of transition-though absorptive capacity constraints remain challenging and need to be addressed 


\section{The distributional impact of aid is expected to be uneven}

$>$ Disruptions in service delivery will be felt by most households across all provinces

D Direct impact of declining aid on the poor is likely to be modest. Likely reasons:

- Only a fraction of aid reaches the poor-The majority of aid was directed not to reducing poverty but to improving security and governance

$>\quad$ Aid has not been well targeted-Direct benefits of aid flows appear to have accrued disproportionately to provinces with less poverty and higher income households

$>$ Impact is expected to be uneven across provinces-larger in conflict provinces and urban centers because they received most of the aid

$>$ Declining aid is likely to aggravate underemployment more than unemployment.

> Research suggests that most aid-financed jobs are "casual" (last less than 6 months)

$>$ Estimates suggest that a $\$ 0.5$ billion decline in the external budget could affect $11,000-18,000$ job opportunities (six-month basis)

> The job impact will be felt by low-skilled workers in construction, transportation, and retail as well as by higher skilled technical professionals who directly work on aid projects. 


\section{Lessons from international experience}

> Abrupt aid cut-offs lead to fiscal implosion, loss of control over security sector, collapse of political authority, and possibly civil war (Somalia)

> Political stability and state consolidation (based on building "inclusive enough" coalitions) are critical for successful transitions (Mozambique, Rwanda, Cambodia, Mali)

- Fragmented, short-term oriented factionalism, "political marketplace" (Sudan) can lead to endemic high levels of violence, and regional "spoilers" can perpetuate conflicts (Democratic Republic of Congo)

$>$ Effective transitions are generally associated with robust economic growth (for example, Mozambique, Rwanda)-less successful transitions with slower or negative economic growth

These lessons indicate the importance of a well-managed transition and highlight the sense of urgency spelled out in the earlier slides 


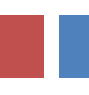

25

Way forward 


\section{The Government should}

$>$ Set effective priorities in a tightening resource-constrained environment

$>$ Spending follows priorities both across and within sectors

$>$ Decisions on new investments take into account future O\&M liabilities and affordability

$>$ Spending on infrastructure demonstrates clear potential for private-sector-led growth

$>$ Continue to strengthen public financial management systems and the budget process, and reduce rent-seeking opportunities and leaks in revenue collection. This will underpin donor confidence and commitment to shift more aid onto the budget and offset political economy pressures on the budget.

> Pursue key public administration reforms, including implementing the Capacity Building for Results initiative to boost capacity in key spending ministries and at sub-national levels, and rationalizing the second civil service.

$>$ Supplant economic growth driven largely by aid-based public investment and consumption, with growth created by fostering a better environment for the private sector to be creative, innovative, and entrepreneurial.

$>$ Manage the allocation of resources to provinces to ensure greater equity and avoid the large differences in average per capita spending across provinces due to external aid 


\section{The international community should}

$>$ Ensure that reductions in international assistance are gradual, predictable, and orderly, since sharp fluctuations in aid, especially abrupt aid cut-offs-can be extremely damaging and lead to state collapse

$>$ Continue to fund the wage and non-wage costs of Afghanistan's security sector until security improves and the size and cost of security become much lower

$>$ Help the government protect the civilian budget, including public investment and O\&M, in the face of the large demands for security spending

$>$ Rationalize the deployment and wage levels of the "second civil service" and develop an orderly plan for its integration into the regular civil service

$>$ Channel a much larger proportion of aid flows through the Afghan government budget to help address fiscal viability and mitigate the adverse economic impacts of declining aid; continue with technical assistance to improve budget execution with emphasis on assistance to provinces

$>$ Assist in reconnecting Afghanistan with world markets by helping remove restrictions on trade and transit, and to encourage the building infrastructure (rail and roads) to realize the potential of mineral wealth 
THANK YOU! 